\title{
Tata Kelola Edem Paru Neurogenik
}

\author{
Riyadh Firdaus*), Bambang J. Oetoro ${ }^{* *}$, Syafruddin Gaus ${ }^{* * *}$, Tatang Bisri ${ }^{* * * *}$ \\ ${ }^{*}$ Departemen Anestesiologi dan Terapi Intensif Fakultas Kedokteran Universitas Indonesia-RS. Dr. Cipto \\ Mangunkusumo-Jakarta, ${ }^{* *}$ Departemen Anestesiologi dan Terapi Intensif Fakultas Kedokteran Universitas \\ Khatolik Atmajaya-Rumah Sakit Mayapada-Tangerang, ${ }^{* * *}$ Departemen Anestesiologi,Terapi Intensif dan \\ Manajemen Nyeri Fakultas Kedokteran Universitas Hasanuddin-Makassar, ${ }^{* * * *}$ Departemen Anestesiologi dan \\ Terapi Intensif, Fakultas Kedokteran Universitas Padjadjaran, RS Hasan Sadikin, Bandung
}

\begin{abstract}
Abstrak
Edem paru neurogenik merupakan salah satu komplikasi pernafasan yang dapat muncul setelah cedera/trauma susunan saraf pusat. Bervariasinya laporan epidemiologi dan patofisiologi edem paru neurogenik dapat menyebabkan misdiagnosis yang dapat memperburuk prognosis pada pasien yang mengalami edem paru neurogenik. Patofisiologi edem paru neurogenik diduga dimulai dari kerusakan pada persarafan autonom pembuluh darah pulmonal dan stimulasi berlebihan dari pusat vasomotor susunan saraf pusat, yang kemudian menyebabkan berbagai perubahan yang terjadi pada pembuluh darah pulmonal hingga disfungsi jantung. Investigasi klinis harus dilakukan hatihati karena manifestasi klinis yang dapat menyerupai edem paru kardiogenik dan non-kardiogenik lainnya, hasil pemeriksaan yang tidak spesifik, dan tidak adanya kriteria diagnosis. Saat ini belum ada pedoman tata kelola edem paru neurogenik yang dapat diterima secara luas, namun berbagai studi dan literatur menyebutkan tata kelola edem paru neurogenik berupa tata kelola suportif airway, breathing, circulation, di samping tata kelola penyebab cedera/ trauma susunan saraf pusat memiliki prognosis yang baik, oleh karena itu identifikasi, investigasi, dan tata kelola edem paru neurogenik harus dilakukan secepatnya. Edem paru neurogenik dapat beresolusi dengan baik dalam 48-72 jam setelah mendapatkan tata kelola yang adekuat.
\end{abstract}

Kata kunci: edem paru neurogenik, kerusakan susunan saraf pusat, tata kelola

JNI 2018;7 (1): 62-70

\begin{abstract}
Neurogenic pulmonary edema is one of respiration complication caused by injury of central nervous system. Due to the vary of neurogenic pulmonary edema epidemiology and pathophysiology leads to misdiagnosed of neurogenic pulmonary edema, which could worsen the clinical condition patients. The pathophysiology of neurogenic pulmonary edema is believed caused by lesion on the autonomic central of vascular pulmonary bed and overactivation of central vasomotor system, which leads to alteration of vascular pulmonary conditions and cardiac dysfunction. Clinical investigation should be done carefully, because the clinical manifestations of neurogenic pulmonary edema mimicking the cardiogenic and non-cardiogenic pulmonary edema, non-spesific diagnostic modalities, and none diagnostic criteria in neurogenic pulmonary edema. Although nowadays none of management guidelines of neurogenic pulmonary edema accepted widely, many study reported the good outcome of supportive management of airway, breathing, and circulation besides the primary management of central nervous system injury. Hence, clinical identifications, investigations, and management of neurogenic pulmonary edema should be done immediately, because of good clinical outcome in $48-72$ hours with adequate management.
\end{abstract}

Management of Neurogenic Pulmonary Edema

Key words: neurogenic pulmonary edema, central nervous system damage, management

JNI 2018;7 (1): 62-70 


\section{Pendahuluan}

Edem paru neurogenik adalah suatu sindrom klinis yang ditandai dengan peningkatan cairan interstitial dan alveolus paru secara mendadak yang tidak dapat dijelaskan oleh faktor atau kelainan pada sistem kardiovaskular dan/atau paru setelah terjadinya cedera atau trauma pada susunan saraf pusat. Insidensi edem paru neurogenik di instalasi gawat darurat mencapai $25 \%$, dengan angka morbiditas mencapai 40 $50 \%$ dan mortalitas mencapai $7-10 \% .{ }^{1}$ Beberapa teori yang menjelaskan patofisiologi edem paru neurogenik adalah peningkatan tekanan hidrostatik kapiler pulmonal, peningkatan permeabilitas kapiler pulmonal, dan disfungsi jantung..$^{2-3}$ Belum ada metode yang digunakan secara luas dan khusus untuk menegakkan diagnosis edem paru neurogenik. Pada umumnya penegakkan diagnosis edem paru neurogenik dilakukan berdasarkan penilaian gejala klinis dan eksklusi terhadap penyebab edem paru lainnya pada pasien dengan cedera atau trauma susunan saraf pusat. ${ }^{4,5}$

Tata laksana utama edem paru neurogenik adalah tatalaksana cedera atau trauma susunan saraf pusat. Tatalaksana suportifedem paru terletak pada tata kelola hemodinamik, termasuk di antaranya adalah penggunaan obat vasoaktif, diuretik, dan terapi cairan. Tata kelola respirasi pada edem paru neurogenik memiliki tujuan memperbaiki ventilasi paru untuk mencegah hipoksemi dan hiperkapni. Tata kelola neurologi terutama terletak pada reduksi tekanan intrakranial. Tata kelola anestesi, walaupun saat ini masih belum dilaporkan secara luas, namun bertujuan untuk menghambat pusat persarafan simpatik pada hipotalamus, batang otak, dan pusat simpatis vasoaktif. ${ }^{4}$ Identifikasi dan tata kelola edem paru neurogenik perlu mendapatkan perhatian khusus karena data epidemiologi dan tata kelola edem paru neurogenik masih kurang dan secara klinis bersifat akut dan sangat mengancam nyawa. ${ }^{4,6}$

\section{Tinjauan Pustaka}

\section{Definisi dan Epidemiologi}

Edem paru neurogenik adalah suatu sindrom klinis yang bersifat akut dan mengancam nyawa yang ditandai dengan peningkatan cairan interstitial dan alveolus paru secara mendadak yang berkaitan dengan cedera/trauma berat pada susunan saraf pusat. Pada praktik klinis, edem paru neurogenik sering mengalami misdiagnosis karena kurangnya perhatian terhadap masalah paru yang muncul dibandingkan dengan cedera/ trauma pada susunan saraf pusat dan pada edem paru neurogenik berat kebanyakan pasien akan meninggal sebelum dilakukan intervensi kegawatdaruratan. ${ }^{2,4}$

Data epidemiologi secara pasti mengenai edem paru neurogenik jarang dilaporkan. Studi literatur yang ditemukan umumnya berupa laporan kasus dan hasil autopsi pasien yang sedikit dan tidak memiliki relevansi secara statistik. Pada pasien dengan perdarahan subaraknoid angka insidensi edem paru neurogenik dilaporkan bervariasi antara $2-42 \%$ dengan angka mortalitas mencapai $10 \%$. Angka kejadian edem paru neurogenik pada cedera kepala berat diperkirakan mencapai $20-25 \%$ dan mencapai $50 \%$ pada pasien cedera kepala traumatik dalam 96 jam setelah kejadian. Insidensi edem paru neurogenik sangat berkaitan dengan usia, keterlambatan operasi, dan presentasi klinis dan radiologi. Pada epilepsi diperkirakan kejadian edem paru neurogenik memiliki insidensi mencapai $30 \%$ dengan angka mortalitas mencapai $80-100 \%$. Walaupun pada laporan insidensi edem paru neurogenik relatif tinggi pada kasus tertentu, secara umum, insidensi kejadian edem paru neurogenik masih relatif rendah, berkisar antara $2-8 \%{ }^{1}$

\section{Etiologi}

Edem paru neurogenik sering terjadi terutama pada perdarahan subaraknoid, cedera kepala traumatik, kejang epilepsi, stroke non-perdarahan, tumor, meningoensefalitis, hidrosefalus, sklerosis multipel, prosedur endovaskular neurologi, dan peningkatan tekanan intrakranial karena blokade VP-shunt tanpa kelainan jantung atau paru yang mendasarinya dengan lonjakan kadar katekolamin diperkirakan sebagai etio-patogenesis pada edem paru neurogenik. ${ }^{6-8}$ Kejang pada epilepsi merupakan penyebab paling banyak edem paru neurogenik, umumnya edem terjadi pada periode postictal. Edem paru neurogenik sebagai 
komplikasi dari perdarahan subaraknoid atau intraserebral dapat terjadi dalam beberapa hari setelah perdarahan dan dapat berulang. Pada sebuah studi terhadap 78 kasus kematian akibat perdarahan subaraknoid, didapatkan kejadian edem paru sebanyak $71 \%$ dan bukti klinis antemortem edem paru pada $31 \%$ pasien. Penyebab lainnya adalah sindrom Guillain-Barre, sklerosis multipel dengan keterlibatan medula, stroke non-perdarahan, poliomielitis bulbar, emboli udara, tumor otak, terapi elektrokonvulsif, meningitis bakteri, cedera medula spinalis servikal, blokade nervus trigeminus, ligasi arteri vertebra, ruptur malformasi av medula spinalis, general anesthesia, kista kolloidal, hidrosephalus, dan sindrom Reye's. ${ }^{7,8}$

\section{Anatomi Susunan Saraf Pusat Terkait Edem Paru}

Dari sudut pandang anatomi, medula oblongata dan hipotalamus memilki peranan penting terhadap kejadian edem paru melalui respon autonom. Medula oblongata posterior adalah suatu struktur pada susunan saraf pusat yang membentuk struktur inferior dasar ventrikel keempat, mencakup area adrenergik 1 dan 5 dan nukleus traktus solitarius. Serabut saraf yang berasal dari area adrenergik 5 akan menuju kolumna intermediolateral medula spinalis torakolumbal, yang merupakan area persarafan simpatis, sedangkan serabut saraf yang melalui area adrenergik 1 akan menuju ke hipotalamus. Serabut saraf pada area adrenergik 1 memiliki peranan penting dalam inhibisi aktivitas sekresi neuroendokrin vasopressin di nukleus supraoptikus dan paraventrikel melalui proyeksi hipotalamus. ${ }^{7,9}$ Cedera/trauma area hipotalamus preoptik lateral dapat menyebabkan vasokonstriksi viseral berat melalui serabut eferen simpatis, yang berakibat pada akumulasi darah ke sirkulasi pulmonal. Lesi pada area hipotalamus anterior berkaitan dengan kejadian edem paru neurogenik berat yang didasari oleh proses peningkatan tekanan arterial sistemik. Lesi atau stimulasi pada area spesifik dapat merangsang pelepasan katekolamin yang kemudian mengakibatkan peningkatan tekanan hidrostatik kapiler pulmonal dan ekstravasasi cairan. ${ }^{10,11}$

\section{Patofisiologi Edem Paru Neurogenik}

Pada paru normal, kebocoran cairan dan protein terjadi melalui celah antar sel endotelial pembuluh kapiler. Cairan dan komponen yang difiltrasi melalui rongga interstitial alveolar berasal dari sirkulasi menuju rongga interstitial alveolar dan peribronkovaskular dan tidak dapat menembus alveolus karena pada lapisan epitelium alveolar memiliki tight junction yang sangat rapat. Gaya hidrostatik yang mengakibatkan perpindahan cairan menembus mikrosirkulasi paru memiliki gaya yang sama besar dengan tekanan hidrostatik kapiler paru, yang dipengaruhi oleh perbedaan tekanan osmotik protein. Melalui aliran pembuluh limfatik, cairan yang berasal dari interstitial tersebut akan diresorpsi menuju aliran sistemik. Pembuluh limfatik merupakan suatu pembuluh kecil yang dapat berkontraksi saat pergerakan pernafasan, aliran limfatik yang berasal dari alveolus akan menuju ke hilum dan kelenjar getah bening regional. Aliran limfatik akan mengalir keluar dari toraks melalui pembuluh yang terdapat pada mediastinum, kemudian menuju ke pembuluh vena besar yang terdapat di daerah leher bawah.

Kecepatan filtrasi resorpsi oleh sistem limfatik ini dapat meningkat sampai beberapa kali, namun hanya sampai batasan tertentu. Edem paru akan terjadi saat laju filtrasi cairan ke dalam paru melebihi laju filtrasi resorpsi sistem limfatik. Patofisiologi edem paru neurogenik merupakan salah satu atau kombinasi mekanisme (1) peningkatan tekanan hidrostatik kapiler pulmonal, (2) perubahan permeabilitas kapiler pulmonal, dan (3) disfungsi jantung., ${ }^{2,10,12}$

Pada cedera/trauma kepala yang disertai/tanpa peningkatan tekanan intrakranial dan penurunan perfusi otak akan menyebabkan pelepasan rangsang simpatis dari beberapa area spesifik susunan saraf pusat. Pelepasan rangsang simpatis ini terutama berasal dari hipotalamus, medula oblongata dan medula spinalis. Pelepasan rangsang simpatis ini dapat mengakibatkan edem paru neurogenik melalui dua mekanisme, yaitu: peningkatan tekanan hidrostatik paru (teori blast) dan peningkatan permeabilitas kapiler pulmonal (teori gangguan permeabiilitas). ${ }^{12}$

Katekolamin, sebuah mediator vasoaktif yang 
beredar di sirkulasi vena akan dilepaskan secara signifikan setelah cedera/trauma susunan saraf pusat memiliki peranan penting dalam kejadian hipertensi pulmonal. Lebih lanjut katekolamin akan menyebabkan vasokontriksi sistemik berat, perpindahan darah dari aliran sistemik menuju aliran paru, yang akan meningkatkan volume cairan darah darah pulmonal. Akibat peningkatan volume cairan darah pada paru, aliran balik pembuluh vena dan tahanan pembuluh sistemik akan meningkat namun, tekanan diastolik ventrikel kiri jantung dan komplians tekanan sistolik akan menurun disertai peningkatan volume ventrikel kiri. Peningkatan volume ventrikel akan meningkatkan tekanan pada fase akhir pengisian ventrikel kiri dan atrium kiri. Lebih lanjut, akan mengakibatkan peningkatan tekanan kapiler pulmonal yang disertai dengan kerusakan lapisan endotelial dan kebocoran cairan menuju interstitial dan alveolus. ${ }^{12}$

Kerusakan neuronal baik secara langsung maupun tidak langsung pada pusat persarafan autonom pembuluh darah pulmonal dan stimulasi berlebihan dari pusat vasomotor susunan saraf pusat menurut literatur dapat menjelaskan kejadian edem paru neurogenik dengan peningkatan tekanan intrakranial. Refleks Hering-Breuer dapat mengakibatkan bradikardi, bronkokonstriksi, gangguan ritme pernafasan, hingga episode henti nafas. Gangguan persarafan autonom, yang dapat diakibatkan oleh aktifitas berlebihan pada persarafan simpatis atau gangguan saraf vagal yang diakibatkan oleh vagotomi atau kerusakan nukleus vagal di medula oblongata dapat menyebabkan edem paru neurogenik yang merupakan komplikasi dari berbagai mekanisme cedera/trauma susunan saraf pusat. ${ }^{13}$

\section{Peningkatan Tekanan Hidrostatik Kapiler Pulmonal (Teori Blast)}

Edem paru neurogenik sering berkaitan dengan kejadian hipertensi pulmonal dan sistemik yang dapat diakibatkan secara sekunder oleh peningkatan tekanan intrakranial ataupun adanya pelepasan katekolamin dalam jumlah besar. Hipertensi pulmonal dan sistemik akan menyebabkan peningkatan volume darah pulmonal akibat perpindahan aliran darah sistemik menuju aliran darah arteri dan vena pulmonal. Akibat dari peningkatan volume darah pulmonal, tekanan hidrostatik pulmonal akan meningkat. Semakin tingginya tekanan hidrostatik intravaskular pulmonal akan menyebabkan kerusakan barotrauma terhadap membran kapiler-alveolar pulmonal. Keadaan edem paru ini akan ditambah melalui edem paru transudatif yang diakibatkan oleh peningkatan tekanan vena pulmonal. Edem paru menurut teori blast menjelaskan bahwa kejadian edem paru sebagai hasil akibat dari dua mekanisme yang saling bersinergi, yaitu peningkatan tekanan hidrostatik kapiler pulmonal dan kerusakan pada membran endotelial pulmonal. ${ }^{1,5}$

Pelepasan katekolamin dalam jumlah besar dapat menyebabkan peningkatan afterload ventrikel kiri. Peningkatan tekanan end-diastolic ventrikel kiri dan atrium kiri secara teori dapat menyebabkan peningkatan tekanan vena pulmonal dan tekanan hidrostatik pulmonal. Peningkatan ringan tekanan atrium kiri $(18-25 \mathrm{mmHg})$ akan menyebabkan edem pada rongga interstitial perimikrovaskular dan peribronkovaskular, dan jika peningkatan tekanan atrium kiri meningkat lebih dari 25 mmHg maka cairan edem akan menembus epitel pulmonal, dan memenuhi alveolus dengan cairan edem rendah-protein. ${ }^{14}$

\section{Peningkatan Permeabilitas Kapiler Pulmonal (Teori Gangguan Permeabilitas)}

Peningkatan permeabilitas kapiler pulmonal dapat disebabkan oleh aktivasi mekanisme persarafan tertentu atau akibat tekanan hidrostatik kapiler pulmonal. Secara teori mekanisme ini lebih dapat menjelaskan kejadian edem paru neurogenik yang memiliki kandungan cairan kaya-protein namun kurang menjelaskan keterkaitan perubahan hemodinamik yang terjadi pada edem paru neurogenik. Dalam hubungannya dengan teori blast, seperti yang telah dijelaskan sebelumnya bahwa kerusakan endotelial pulmonal lebih lanjut dapat menyebabkan perubahan pada permeabilitas kapiler pulmonal yang akan berakibat pada kebocoran protein plasma menuju rongga interstitial dan alveolus. Edem paru akibat mediasi persarafan dapat terjadi tanpa disertai peningkatan tekanan arterial pulmonal. ${ }^{7,10}$ 


\section{Disfungsi Jantung}

Beberapa studi menunjukkan bahwa edem paru dan cedera miokardium dapat terjadi setelah cedera/trauma pada susunan saraf pusat. Pada kardiomiopati Takotsubo akibat cedera/ trauma susunan saraf pusat yang berat, dapat menyebabkan edem paru kardiogenik akibat disfungsi diastolik, lusitrofi, dan hipokinetik global yang terjadi secara transien. ${ }^{15}$ Sindrom neurogenic stunned myocardium terjadi akibat aktivasi persarafan simpatis, terutama pelepasan katekolamin, ditandai dengan disfungsi ventrikel kiri, bradikardi, disertai perubahan EKG pada komplek QRS, segmen-ST, gelombang-T, dan pemanjangan interval Qtc dapat terjadi hingga hingga hari ke-14 setelah cedera/trauma pada susunan saraf pusat. Perubahan pola EKG yang terjadi menyerupai gambaran iskemi miokardium, namun tanpa gambaran penyakit koroner akut. Walaupun demikian kardiomiopati Takotsubo dan neurogenic stunned myocardium dapat memiliki gambaran klinis yang sama. ${ }^{5,16}$

\section{Manifestasi Klinis}

Manifestasi klinis edem paru neurogenik dapat menyerupai acute respiratory distress sindrome (ARDS) dan edem paru kardiogenik, bergantung pada beratnya cedera/trauma susunan saraf pusat yang terjadi. Gambaran klinis yang sering terjadi adalah episode dispnea akut, takipnea, sianosis, hipoksi, dan pucat. Pada pemeriksaan auskultasi dapat ditemukan ronki bilateral terutama pada kedua basal paru. Pada pipa endotrakeal dapat ditemukan sputum berbusa dengan warna kemerahan. ${ }^{2,14}$ Beberapa studi dilakukan untuk melakukan investigasi terhadap penyebab edem paru, hidrostatik atau permeabilitas, Merenkov, dkk melaporkan bahwa pemeriksaan bedside lung ultrasound dapat mengidentifikasi edem paru yang terjadi, mengeksklusi keterlibatan kardiak, dan sebagai panduan pada tata kelola cairan. Namun penggunaan bedside lung ultrasound tidak dapat menentukan secara kuantitatif extravascular lung water (EVLWI), yang merupakan parameter paling akurat dan sensitif dalam penilaian terhadap edem paru. Pulse index continous cardiac output (PiCCO) adalah sebuah metode yang dikembangkan untuk mendeteksi global end diastolic volume index
(GEDVI), intrathoracic blood volume index (ITBVI) dan EVLWI melalui teknik termodilusi transpulmonal. PiCCO dapat menjadi metode pemantauan curah jantung yang lebih baik dibandingkan kateterisasi arteri pulmonal pada berbagai kelompok pasien. Penggunaan PiCCO yang dikombinasikan dengan metode lain dapat membedakan tipe edem pulmonal yang terjadi pada pasien dengan perdarahan subaraknoid. Penulis lain mengajukan klasifikasi bukti edem paru berdasarkan termodilusi transpulmonal, yaitu: peningkatan volume hidrostatik yang diakibatkan oleh reduksi curah jantung akibat disfungsi jantung (edem paru kardiogenik), dan hipovolemik intravaskular yang diakibatkan oleh peningkatan permeabilitas mikrovaskular pulmonal (edem paru nonkardiogenik)., ${ }^{917}$

\section{Diagnosis dan Diagnosis Banding}

Belum adanya perangkat yang dapat menegakan diagnosis edem paru neurogenik secara akurat menyebabkan penegakan diagnosis edem paru neurogenik saat ini hanya berdasarkan eksklusi terhadap penyebab edem paru lainnya. Sebuah kriteria diagnosis yang dapat digunakan untuk penegakan diagnosis edem paru neurogenik: ${ }^{5}$ gambaran infiltrat paru bilateral pada radiologi toraks, rasio $\mathrm{PaO}_{2} / \mathrm{FiO}_{2}<200$, tidak ada bukti hipertensi atrium kiri, cedera/trauma susunan saraf pusat cukup berat (dapat menyebabkan peningkatan tekanan intrakranial), tidak ada penyebab gangguan pernafasan akut atau ARDS.

Investigasi klinis pada edem paru neurogenik dapat dilakukan dengan pemeriksaan toraks, EKG, ekokardiografi transtoraks dan kateterisasi arteri pulmonal. Kondisi klinis lainnya yang dapat menyerupai edem paru neurogenik diantaranya adalah gagal jantung kongestif, pneumonia, ARDS, ventilation-induced lung injury, dan kontusio paru. ${ }^{4,14}$

\section{Tata Kelola Edem Paru Neurogenik}

Tata kelola edem paru neurogenik memiliki strategi tata kelola cedera/trauma susunan saraf pusat yang mendasari dengan salah satu tujuan untuk mengakhiri aktivitas persarafan simpatis yang memicu kejadian pada paru, dan mencegah cedera susunan saraf pusat sekunder yang 
diakibatkan oleh hipoksi dan hipotensi. ${ }^{1,2}$

\section{Tata Kelola Hemodinamik}

Terapi farmakologi dalam hemodinamik edem paru neurogenik sangat bergantung pada kondisi klinis, cederapenyerta, dan cederayang mendasari. Status volume cairan pada pasien dengan cedera/ trauma susunan saraf pusat sebaiknya berada pada status euvolemia. Pada pasien dengan instabilitas hemodinamik penilaian fungsi jantung dengan kateterisasi arteri pulmonal, ekokardiografi, atau Doppler esofagus dapat membantu dalam menentukan terapi. Kejadian hipotensi memiliki hubungan dengan buruknya prognosis pada pasien dengan cedera/trauma susunan saraf pusat. Oleh karena itu menjaga tekanan darah berada di atas autoregulasi aliran darah otak terendah sangatlah penting. Salah satu target dalam tata kelola tekanan darah harus mencapai nilai MAP yang berkisar $70 \mathrm{mmHg}$ atau tekanan perfusi otak $60 \mathrm{mmHg}$, jika tekanan intrakranial berada dalam batas normal. Hantaran oksigenasi susunan saraf pusat dapat ditingkatkan dengan meningkatkan tekanan perfusi otak dan aliran darah otak yang memiliki efek menguntungkan juga terhadap peningkatan $\mathrm{SjO}_{2}$ dan $\mathrm{PbrO}_{2}$. Normalisasi kadar $\mathrm{PCO}_{2}$ dalam darah dan meningkatkan tekanan perfusi otak melalui reduksi volume intrakranial (tanpa menggunakan hiperventilasi), ekspansi volume pembuluh darah, atau vasopressor merupakan manuver untuk meningkatkan aliran darah otak yang sering digunakan. ${ }^{4}$

Dobutamine dapat memperbaiki cardiac index, left ventricular stroke work index, tekanan pulmonal, dan rasio $\mathrm{PaO}_{2} / \mathrm{FiO}_{2}$. Rekomendasikan penggunaan inotropik dengan kombinasi vasodilator perifer sebagai terapi lini pertama dengan kateterisasi arteri pulmonal sebagai monitor terapi. ${ }^{4,6}$

\section{Tata Kelola Respirasi}

Karena edem paru neurogenik terjadi akibat cedera/trauma susunan saraf pusat berat dan sering terjadi bersamaan dengan penurunan kesadaran akibat cedera/trauma susunan saraf pusat, proteksi jalan nafas harus dilakukan dengan segera untuk menjamin oksigenasi yang adekuat, mencegah pneumonia aspirasi dan hipoksi susunan saraf pusat dan organ lainnya lebih lanjut. Tindakan intubasi harus dilakukan secara hati-hati untuk mencegah spasme jalan nafas dan peningkatan tekanan intrakranial lebih lanjut. Intubasi endotrakeal dapat meningkatkan kejadian iskemi otak terutama pada pasien kritis dengan gangguan perfusi otak, seperti pada stroke iskemi atau iskemi otak pada stroke perdarahan. Mean arterial pressure (MAP) yang rendah dapat menyebabkan penurunan pada tekanan perfusi otak sehingga terjadi iskemi otak. Tindakan intubasi endotrakeal sebaiknya dilakukan ketika tekanan perfusi otak $>50-60 \mathrm{mmHg}$, apabila tidak memungkinkan maka vasopressor dapat digunakan untuk mencapai target tekanan perfusi otak. Penggunaan ketamine sangat dianjurkan sebagai premedikasi intubasi endotrakeal pada pasien dengan instabilitas hemodinamik. Penggunaan $\mathrm{ETCO}_{2}$ setelah intubasi dapat berguna untuk mencegah hiperventilasi. ${ }^{18}$

Cedera paru akut dan ARDS dapat terjadi bersamaan pada pasien dengan cedera/trauma susunan saraf pusat dan memiliki hubungan dengan prognosis yang buruk. Ventilasi dengan strategi lung-protective dilakukan untuk mencegah cedera paru iatrogenik. Restriksi volume tidal dapat digunakan sebagai tata kelola dalam edem paru neurogenik, dengan penggunaan PEEP untuk menjaga pengembangan rongga alveolus. Volume tidal yang rendah $\leq 6$ $\mathrm{mL} / \mathrm{KgBB}$ dan tekanan jalan nafas statik $\leq$ $30 \mathrm{cmH}_{2} 0$ dapat menurunkan angka kejadian mortalitas pada berbagai gangguan pernafasan akut maupun ARDS. ${ }^{2,5,19}$ Ekstubasi pada pasien dengan cedera/trauma susunan saraf pusat dan edem paru neurogenik dapat dipertimbangkan sesuai dengan kondisi gagal nafas, setelah tata kelola fase akut teratasi dan peningkatan tekanan intrakranial tidak lagi menjadi masalah. Penilaian kemampuan bernafas secara spontan dapat dilakukan dengan protokol respiratory-care dan masalah pada jalan nafas yang diakibatkan oleh perubahan tingkat kesadaran dan refleks jalan nafas terkait cedera/trauma susunan saraf pusat. ${ }^{19}$

\section{Tata Kelola Anestesi}

Beberapa pendapat menyatakan bahwa anestesi dengan level yang dalam dapat menginhibisi 
hipotalamus, batang otak, dan pusat simpatis vasoaktif sehingga dapat menghambat perkembangan edem paru neurogenik. Propofol dan midazolam sering digunakan sebagai sedatif pada pasien dengan cedera/trauma susunan saraf pusat akut. Kedua obat ini dapat menurunkan aliran darah otak dengan menurunkan laju metabolik otak, yang kemudian akan menurunkan tekanan intrakranial. Namun penggunaan infus propofol dosis tinggi memiliki hubungan dengan kolaps sistem kardiovaskular dan kematian pada pasien dengan kerusakan susunan saraf pusat akut. $^{12}$

\section{Tata Kelola Neurologi}

Tata kelola neurologi harus dapat menjaga aliran darah susunan saraf pusat untuk mencegah kerusakan lebih lanjut. Tekanan perfusi susunan saraf pusat yang adekuat dapat dilakukan dengan menurunkan peningkatan tekanan intrakranial dan mencegah hipotensi. Selain itu keadaan hipoksemi, hiperglikemi, kejang, atau demam harus diatasi dengan baik. Hiperventilasi pada cedera/trauma susunan sarafpusat memilki banyak perdebatan. ${ }^{19}$ Menurunkan volume intrakranial dapat dilakukan dengan terapi cairan osmotik. Penggunaan manitol atau saline hipertonik dalam beberapa laporan dapat menunjukkan hasil yang baik dalam cedera/trauma susunan saraf pusat. Pada keadaan peningkatan tekanan intrakranial yang diakibatkan oleh perdarahan, prosedur pembedahan dengan evakuasi bekuan perdarahan atau perdarahan harus dilakukan dengan tujuan mengurangi tekanan intra kranial. ${ }^{19}$

\section{Tata Kelola Farmakologi}

Terapi farmakologi tidak selalu rutin digunakan pada tata kelola edem paru neurogenik. Beberapa literatur mengatakan beberapa terapi farmakologi dapat digunakan pada edem paru neurogenik, namun, studi efikasi terapi tersebut jarang dilaporkan karena kebanyakan edem paru neurogenik bersifat self-limiting. Beberapa terapi farmakologi yang dapat digunakan pada edem paru neurogenik adalah antagonis adrenergik- $\alpha$ (phentolamine), dobutamine, dan klorpromazine. Penggunaan kortikosteroid dapat digunakan pada beberapa kondisi susunan saraf pusat seperti, tumor otak dan sklerosis multipel, namun pada trauma otak tidak memiliki efek yang menguntungkan. Secara spesifik beberapa studi telah melaporkan penggunaan phentolamine pada kasus edem paru neurogenik dengan luaran klinis baik yang ditandai dengan peningkatan oksigenasi dan perbaikan hemodinamik..$^{5,710}$

\section{Prognosis}

Edem paru neurogenik harus segera dipikirkan pada pasien dengan cedera/trauma susunan saraf pusat yang mengalami kejadian sesak nafas. Pasien dengan edem paru neurogenik memiliki angka mortalitas yang tinggi, namun perbaikan dapat terjadi secara cepat pada pasien dengan prognosis baik. Prognosis pada edem paru neurogenik secara umum sangat bergantung pada cedera/trauma susunan saraf pusat yang mendasari dan cedera miokardium yang terjadi. Angka mortalitas pada edem paru neurogenik dilaporkan antara $7-10 \%$. Pada beberapa studi melaporkan mortalitas edem paru neurogenik mencapai $50 \%$ dan lebih tinggi terutama pada kasus edem paru neurogenik fatal. Berbagai studi dilakukan untuk menilai baik outcome dan prognosis edem paru neurogenik. Kerusakan area hipotalamus pada pasien dengan edem paru neurogenik memiliki prognosis yang lebih buruk. ${ }^{5}$ Peningkatan serum laktat yang terjadi dalam 1 jam setelah onset perdarahan subaraknoid nontraumatik merupakan faktor independen yang yang berkaitan dengan edem paru neurogenik onset dini. ${ }^{7,20}$

\section{Simpulan}

Edem paru neurogenik merupakan suatu sindrom klinis bersifat akut dan mengancam nyawa sangat membutuhkan perhatian khusus, karena secara klinis menurut studi dan literatur sering mengalami misdiagnosis. Di samping kondisi klinis dapat menyerupai kondisi klinis edem paru kardiogenik, hingga saat ini belum ada tools yang dapat digunakan secara luas dalam melakukan investigasi klinis ataupun menegakkan diagnosis edem paru neurogenik. Berbagaiteoripatofisiologi yang diajukan dalam edem paru neurogenik dapat digunakan sebagai dasar dalam investigasi klinis dan pemilihan terapi yang akan digunakan. Tata kelola edem paru neurogenik harus mencakup 
tata kelola cedera/trauma susunan saraf pusat yang mendasari dengan salah satu tujuan untuk mengakhiri aktivitas persarafan simpatis yang memicu kejadian pada paru dan tata kelola suportif hemodinamik, respirasi, anestesi dan neurologi. Pada umumnya dengan tata kelola yang adekuat respon yang baik dapat dicapai dalam 48-72 jam dengan tata kelola yang adekuat. Walaupun demikian penulis berpendapat bahwa, hingga saat ini masih dibutuhkan studi lebih lanjut dalam hal epidemiologi, patofisiologi, diagnosis dan tatakelola edem paru neurogenik karena data studi dan literatur mengenai edem paru neurogenik masih belum dapat digunakan secara luas.

\section{Daftar Pustaka}

1. Ridenti FAS. Neurogenic pulmonary edema: a current literature review. Rev Bras Ter Intensiva. 2012 Mar;24(1):91-6.

2. Busl KM, Bleck TP. Neurogenic pulmonary edema. Critical Care Medicine. 2015 Aug;43(8):1710-5.

3. Šedý J, Urdzíková L, Likavčanová K, Hejcl A, Jendelová P, Syková E. A new model of severe neurogenic pulmonary edema in spinal cord injured rat. Neuroscience Letters. 2007 Aug;423(2):167-71.

4. O'Leary R, McKinlay J. Neurogenic pulmonary oedema. Contin Educ Anaesth Crit Care Pain. 2011 May 17;11(3):87-92.

5. Davison DL, Terek M, Chawla LS. Neurogenic pulmonary edema. Crit Care. 2012 Dec 12;16(2):212.

6. Baumann A, Audibert G, McDonnell J, Mertes PM. Neurogenic pulmonary edema. Acta Anaesthesiol Scand. 2007 Apr;51(4):447-55.

7. Šerić V, Roje-Bedeković M, Demarin V. Neurogenic pulmonary edema. Acta Clin Croat. 2004;43:389-95.

8. Zhao H, Lin G, Shi M, Gao J, Wang Y, Wang
$\mathrm{H}$, et al. The mechanism of neurogenic pulmonary edema in epilepsy. J Physiol Sci. 2013 Dec 31;64(1):65-72.

9. Mutoh T, Kazumata K, Mutoh TU, Taki Y, Ishikawa T. Transpulmonary thermodilutionbased management of neurogenic pulmonary edema after subarachnoid hemorrhage. The American Journal of the Medical Sciences. ElsevierMasson SAS;2015 Nov 1;350:415-9.

10. Toma G, Amcheslavsky V, Zelman V, DeWitt DS, Prough DS. Neurogenic pulmonary edema: pathogenesis, clinical picture, and clinical management. Semin Anesth. 2003 Dec 31;23(3):221-9.

11. Darragh TM, Simon RP. Nucleus tractus solitarius lesions elevate pulmonary arterial pressure and lymph flow. Ann Neurol. 1985 Jun;17(6):565-9.

12. Šedý J, Kuneš J, Zicha J. Pathogenetic mechanisms of neurogenic pulmonary edema. Journal of Neurotrauma. 2015;32(15):113545.

13. Onen MR, Yilmaz I, Ramazanoglu L, Tanrıverdi O, Aydin MD, Kanat A, et al. Rational roots of sympathetic overactivity by neurogenic pulmonary edema modeling arising from sympathyco-vagal imbalance in subarachnoid hemorrhage: an experimental study. World Neurosurgery. Elsevier Ltd; 2016 Apr 27;:1-24.

14. Ware LB, Matthay MA. Clinical practice. acute pulmonary edema. N Engl J Med. 2005 Dec 29;353(26):2788-96.

15. Lee VH, Connolly HM, Fulgham JR, Manno EM, Brown RD, Wijdicks EFM. Tako-tsubo cardiomyopathy in aneurysmal subarachnoid hemorrhage: an underappreciated ventricular dysfunction. J Neurosurg. 2006 Aug;105(2):264-70.

16. Bahloul M, Chaari AN, Kallel H, Khabir A, Ayadi A, Charfeddine H, et al. Neurogenic 
pulmonary edema due to traumatic brain injury: evidence of cardiac dysfunction. Am J Crit Care. 2006 Sep;15(5):462-70.

17. Lin X, Xu Z, Wang P, Xu Y, Zhang G. Role of PiCCO monitoring for the integrated management of neurogenic pulmonary edema following traumatic brain injury: A case report and literature review. Exp Ther Med. 2016 Oct;12(4):2341-7.

18. Fontes RBV, Aguiar PH, Zanetti MV, Andrade F, Mandel M, Teixeira MJ. Acute neurogenic pulmonary edema: case reports and literature review. J Neurosurg Anesthesiol. 2003 Apr;15(2):144-50.

19. Deem S. Management of acute brain injury and associated respiratory issues. Respir Care. 2006 Apr;51(4):357-67.

20. Šedý J, Zicha J, Kuneš J, Jendelová P, Syková E. Mechanisms of neurogenic pulmonary edema development. Physiol Res. 2008;57(4):499-506. 